\title{
Caseins as source of bioactive peptides
}

\author{
Sofia V. Silva, F. Xavier Malcata* \\ Escola Superior de Biotecnologia, Universidade Católica Portuguesa, Rua Dr. António Bernardino de Almeida, P-4200-072 Porto, Portugal
}

Keywords: Dairy products; Proteins; Caseins; Proteolysis

\begin{abstract}
Biologically active peptides are of particular interest in food science and nutrition because they have been shown to play physiological roles, including opioid-like features, as well as immunostimulating and anti-hypertensive activities, and ability to enhance calcium absorption. Hidden or inactive in the amino-acid sequence of dairy proteins, they can be released or activated in vivo during gastrointestinal digestion, or upstream during food processing via specific, enzyme-mediated proteolysis. Caseins, in either milk or dairy products (e.g. cheese), are important sources of those peptides; their biological significance, their impact on human health and the manufacture of novel functional food ingredients therefrom have been subject to intensive research, which will be briefly presented and critically discussed in this review.
\end{abstract}

\section{Contents}

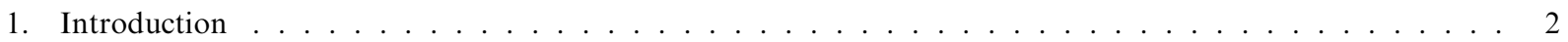

2. Effect on the cardiovascular system . . . . . . . . . . . . . . . . . . . . . . 2

2.1. Antithrombotic peptides . . . . . . . . . . . . . . . . . . . . . 2

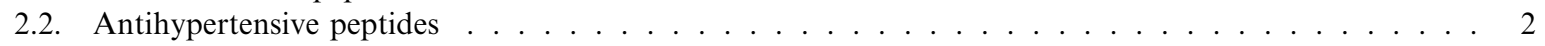

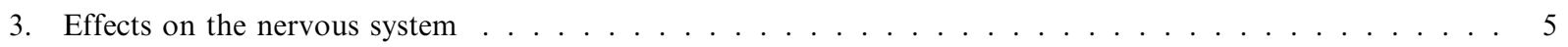

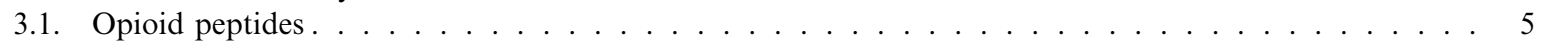

4. Effects on the immune system . . . . . . . . . . . . . . . . . . . . . . 7

4.1. Immunomodulating peptides . . . . . . . . . . . . . . . . . . . . . 7

4.2. Antimicrobial peptides . . . . . . . . . . . . . . . . . . . . . . . . 9

5. Effects on the nutrition system . . . . . . . . . . . . . . . . . . . . . . 9

5.1. Caseinophosphopeptides . . . . . . . . . . . . . . . . . . . . . . 9

5.2. Glycomacropeptide . . . . . . . . . . . . . . . . . . . . . . 11

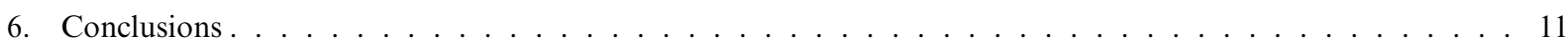

References. ....................................11

*Corresponding author. Tel.: + 351-2255-80004; fax: + 351-22-5090351.

E-mail address: xmalcata@esb.ucp.pt (F.X. Malcata). 


\section{Introduction}

Casein is the main proteinaceous component of milk, where it accounts for ca. $80 \%$ of the total protein inventory. Until recently, the main physiological role of casein in the milk system was widely accepted to be a source of amino acids required by growth of the neonate. However, the dominant physiological feature of the casein micelle system has more recently been proven to be the prevention of pathological calcification of the mammary gland (Holt, 1997).

While no specific physiological property has been proposed for the whole casein system (or its individual fractions, for that matter), various peptides hidden (or inactive) in the amino-acid sequence have been the subject of increasingly intense studies. Much work regarding those peptides, which are known to possess bioactivities, is currently underway regarding their release via selective enzymatic hydrolysis. Until now, such release has been demonstrated primarily in vitro, and to a lower extent in vivo using animal models. Experimental verification of the effectiveness of such bioactive peptides involving human subjects is, however, still scarce. Due to the increasing awareness of the effect of food ingredients upon promotion of health, several publications have arisen that cover recent advances on milk peptide research (Clare, Catignani, \& Swaisgood, 2003; Florisa, Recio, Berkhout, \& Visser, 2003; Janecka, Fichna, \& Janecki, 2004; Kilara \& Panyam, 2003; Kitts \& Weiler, 2003; Korhonen \& Pihlanto, 2003; Lonnerdal, 2003; Meisel \& FitzGerald, 2003; Pellegrini, 2003; Pihlanto \& Korhonen, 2003; Teschemacher, 2003; Wal, 2002; Walker-Smith, 2003).

This paper intends to provide an overview of the major classes of bioactive peptides putatively derived from caseins, which play a role in the nervous, cardiovascular, digestive and immune systems (Fig. 1), and a brief critical discussion of the most recent data made available in the literature regarding that growing family of molecules.

\section{Effect on the cardiovascular system}

Functional peptides derived from casein, present in either milk or dairy products, have been shown to have effects in the cardiovascular system, mainly via antithrombotic and antihypertensive features (Tables 1 and 2, respectively).

\section{Antithrombotic peptides}

The mechanisms involved in the clotting of milk, defined as the interaction of $\kappa$-casein with coagulating enzyme, and in the clotting of blood, defined as the interaction of fibrinogen with thrombin, have been proved to be similar in nature (Fiat, Migliore, \& Jollès, 1993; Jollès, 1975; Jollès \& Henschen, 1982). In addition, structural homologies between the undecapeptide (viz. residues 106-116) from cow's $\kappa$-casein, on the one hand, and the C-terminal dodecapeptide (viz. residues 400-411) of human fibrinogen $\gamma$-chain, on the other, have been duly reported (Jollès, LoucheuxLefebvre, \& Henschen, 1978). Indeed, three amino-acid residues (viz. $\mathrm{Ile}_{108}, \mathrm{Lys}_{112}$ and $\mathrm{Asp}_{115}$ ) of the aforementioned undecapeptide of $\kappa$-casein are in a homologous position when compared with the human fibrinogen $\gamma$-chain (Fiat \& Jollès, 1989). Casoplatelins, which are casein-derived peptides (f106-116, f106-112 and f113-116), are inhibitors of both the aggregation of ADP-activated platelets and the binding of human fibrinogen $\gamma$-chain to a specific receptor region on the platelet surface (Fiat \& Jollès, 1989; Jollès et al., 1986; Schlimme \& Meisel, 1995). Furthermore, the $\kappa$-casein fragment f103-111 can prevent blood clotting through inhibition of platelet aggregation, but is not able to affect fibrinogen binding to ADP-treated platelets (Fiat et al., 1993).

More recently, it was reported that $\kappa$-caseinoglycopeptides from several animal species are a source of antithrombotic peptides. The sequence of amino acids in f106-171 of sheep's $\kappa$-casein, known as $\kappa$-caseinoglycopeptide, was shown to decrease thrombin- and collageninduced platelet aggregation in a dose-dependent manner (Qian, Jollès, Migliore-Samour, Schoentgen, \& Fiat, 1995). In the plasma of 5-day-old new borns, after breast feeding or ingestion of cow's milk-based formulae, antithrombotic peptides were detected, which had been derived from human and bovine $\kappa$-caseinoglycopeptides, respectively (Chabance et al., 1995).

\section{Antihypertensive peptides}

Blood pressure regulation (and hypertension, when it cannot be ensured) is partially dependent on the reninangiotensin system; renin acts on angiotensinogen, thus releasing angiotensin $I$ that is further converted into the active peptide hormone angiotensin II, a vasoconstrictor, by the angiotensin-converting enzyme (ACE). Angiotensin II inactivates bradykinin (a vasodilator); moreover, it increases the production of aldosterone, which decreases the renal output while increasing water retention (Fiat et al., 1993; Maruyama et al., 1987a; Maruyama, Mitachi, Tanaka, Tomizuka, \& Suzuki, 1987b; Tirelli, de Noni, \& Resmini, 1997).

Maruyama and Suzuki (1982) reported that tryptic hydrolysates of casein inhibited the in vitro activity of ACE; those peptides derived from casein, known as casokinins, correspond to f23-24, f23-27 and f194-199 of bovine $\alpha_{\mathrm{s} 1}$-casein B, as well as to f177-183 and f193202 of bovine $\beta$-casein (Maruyama \& Suzuki, 1982; Maruyama et al., 1987a,b; Meisel \& Schlimme, 1994). 


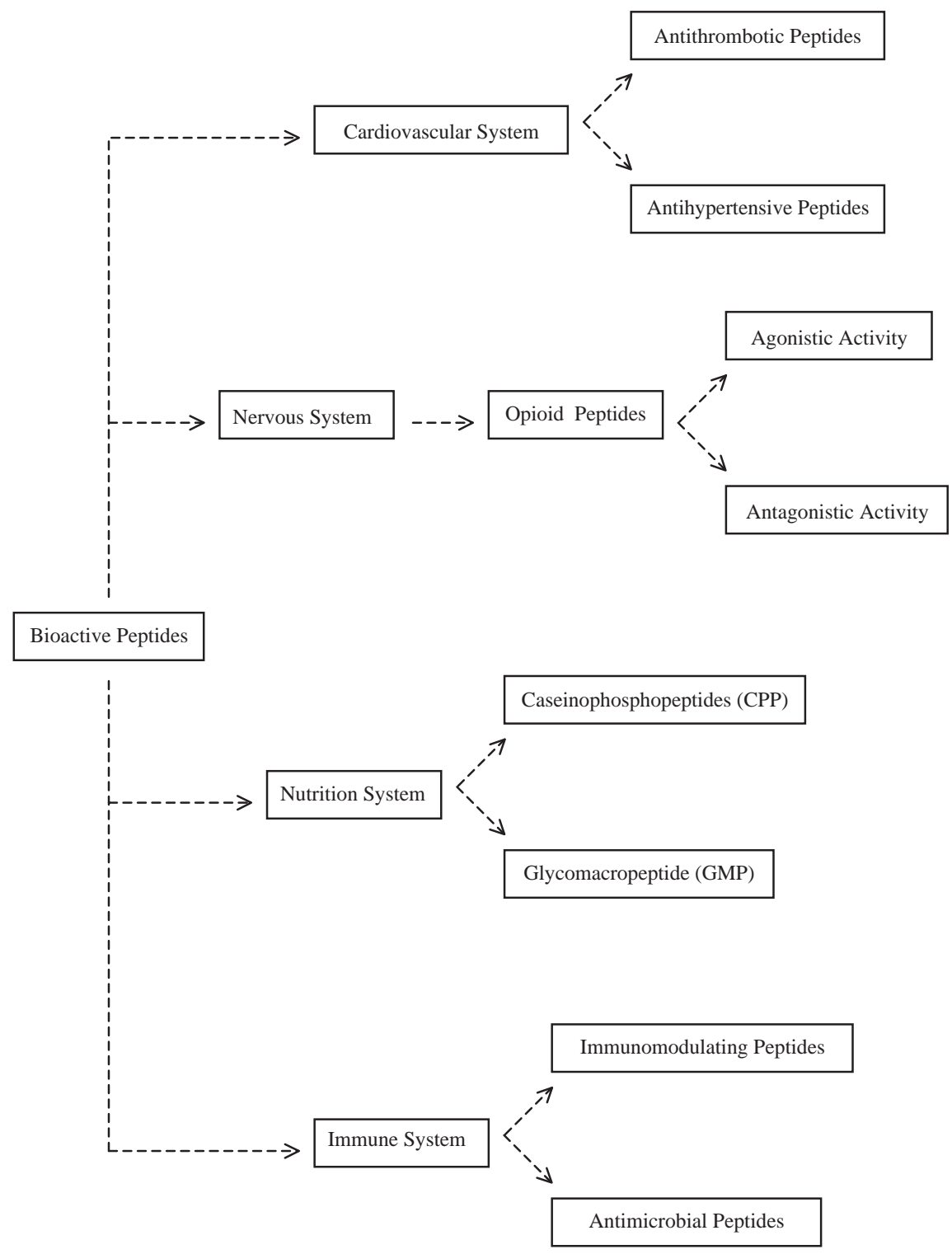

Fig. 1. Functions of bioactive peptides from caseins.

Table 1

Antithrombotic peptide sequences in the primary structure of caseins

\begin{tabular}{llll}
\hline Casein Type & Peptide sequence & Amino acid segment & References \\
\hline$\kappa$-casein (bovine) & $103-111$ & LSFMAIPPK & Fiat et al. (1993) \\
& $106-116$ & MAIPPKKNQDDK & Fiat and Jollès (1989); Jollès et al. (1986); Schlimme and Meisel (1995) \\
& $106-112$ & MAIPPKK & Fiat and Jollès (1989); Jollès et al. (1986); Schlimme and Meisel (1995) \\
& $113-116$ & NQDK & Fiat and Jollès (1989); Jollès et al. (1986); Schlimme and Meisel (1995) \\
\hline
\end{tabular}

Pihlanto-Leppälä, Rokka, and Korhonen (1998) studied the ACE-inhibitory activity of peptides from milk whey and from casein proteins fermented with lactic acid bacteria, and hydrolysed afterward by digestive enzymes; the fermentation of milk proteins by starters did not produce ACE-inhibitory peptides, but subsequent hydrolysis led to ACE-inhibitory activity. The

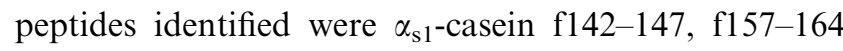
and f194-199, and $\beta$-casein f108-113, f177-183 and f193-198, as well as two others from whey proteins. The latter two were shown to be less active than the caseinderived peptides; among these, the highest ACEinhibitory activity was accounted for by the peptides derived from $\alpha_{\mathrm{s} 1}$-casein. Other anti-hypertensive 
Table 2

Antihypertensive peptide sequences in the primary structure of caseins

\begin{tabular}{|c|c|c|c|}
\hline Casein type & Peptide sequence & Amino-acid segment & References \\
\hline \multirow[t]{6}{*}{$\alpha_{\mathrm{s} 1}$ (bovine) } & $23-24$ & $\mathrm{FF}$ & $\begin{array}{l}\text { Maruyama and Susuki (1982); Maruyama et al. (1987a); Meisel } \\
\text { and Schlimme (1994) }\end{array}$ \\
\hline & $23-27$ & FFVAP & $\begin{array}{l}\text { Maruyama and Susuki (1982); Maruyama et al. (1987a); Meisel } \\
\text { and Schlimme (1994) }\end{array}$ \\
\hline & $102-109$ & KKYKVPQ & Gómez-Ruiz et al. (2002) \\
\hline & $142-147$ & LAYFYP & Pihlanto-Leppälä et al. (1998) \\
\hline & $157-164$ & DAYPSGAW & Pihlanto-Leppälä et al. (1998) \\
\hline & 194-199 & TTMPLW & $\begin{array}{l}\text { Maruyama and Susuki (1982); Maruyama et al. (1987a); Meisel } \\
\text { and Schlimme (1994); Pihlanto-Leppälä et al. (1998) }\end{array}$ \\
\hline \multirow[t]{6}{*}{$\alpha_{\mathrm{s} 2}$ (bovine) } & $174-179$ & FALPQY & Tauzin, Miclo, and Gaillard (2002) \\
\hline & $174-181$ & FALPQYLK & Tauzin, Miclo, and Gaillard (2002) \\
\hline & $189-197$ & AMKPWIQPK & Maeno, Yamamoto, and Takano (1996) \\
\hline & $189-193$ & AMKPW & Maeno, Yamamoto, and Takano (1996) \\
\hline & $190-197$ & MKPWIQPK & Maeno, Yamamoto, and Takano (1996) \\
\hline & 198-202 & TKVIP & Maeno, Yamamoto, and Takano (1996) \\
\hline \multirow[t]{7}{*}{$\beta$ (bovine) } & $74-76$ & IPP & Nakamura et al. (1995) \\
\hline & $84-86$ & VPP & Nakamura et al. (1995) \\
\hline & $108-113$ & EMPFPK & Pihlanto-Leppälä et al. (1998) \\
\hline & $177-183$ & AVPYPQR & $\begin{array}{l}\text { Maruyama and Susuki (1982); Maruyama et al. (1987a); Meisel } \\
\text { and Schlimme (1994) }\end{array}$ \\
\hline & $193-198$ & YQEPVL & Pihlanto-Leppälä et al. (1998) \\
\hline & 193-202 & YQEPVLGPVRGPFPI & $\begin{array}{l}\text { Maruyama and Susuki (1982); Maruyama et al. (1987a); Meisel } \\
\text { and Schlimme (1994) }\end{array}$ \\
\hline & 199-204 & GPVRGPFPIIV & Nakamura et al. (1995) \\
\hline$\kappa$ (bovine) & $108-110$ & IPP & Nakamura et al. (1995) \\
\hline \multirow[t]{2}{*}{$\gamma$-casein (bovine) } & $108-113$ & EMPFPK & Perpetuo, Juliano, and Lebrun (2003) \\
\hline & $114-121$ & YPVEPFTE & Perpetuo, Juliano, and Lebrun (2003) \\
\hline
\end{tabular}

peptides could be pinpointed in the primary sequence of human $\beta$ - and $\kappa$-caseins (Kohmura et al., 1989; Kohmura, Nio, \& Ariyoshi, 1990; Shah, 2000).

Few studies exist concerning $\alpha_{\mathrm{s} 2}$-casein-which accounts for ca. $10 \%\left(\mathrm{w} \mathrm{w}^{-1}\right)$ of the bovine casein system, owing to its poor solubility and difficult purification. The few peptides already identified to derive from bovine $\alpha_{\mathrm{s} 2}$-casein exhibit weak ACE-inhibition; those peptides correspond to f189-193, f189-197, f190-197 and f198-202 (Maeno, Yamamoto, \& Takano, 1996). Studies by Tauzin, Miclo, and Gaillard (2002) on a tryptic digest of bovine $\alpha_{\mathrm{s} 2}$-casein permitted detection of several casokinins. Some exhibited $\mathrm{IC}_{50}$ values close to those that characterise the most potent peptides found in milk protein hydrolysates - two peptides, f174-181 and $\mathrm{f} 174-179$, had $\mathrm{IC}_{50}$ values very low compared with that of captopril, and were inhibitors of ACE. Whether such peptides and the whole tryptic hydrolysate arise in vivo needs further experimental confirmation (Tauzin et al., 2002). Two new peptides generated by tryptic hydrolysis of casein have just been found to display bradykinin-potentiating activity on isolated guinea pig ileum. The peptides Glu-Met-Pro-Phe-Pro-Lys and Tyr-
Pro-Val-Glu-Pro-Phe-Thr-Glu originate from the $\gamma$ casein sequences, f108-113 and f114-121; the latter showed an in vitro inhibition effect upon ACE (Perpetuo, Juliano, \& Lebrun, 2003).

Karaki et al. (1990) detected a decrease in blood pressure in spontaneously hypertensive rats following oral administration of tryptic hydrolysates of milk casein. Two potent ACE-inhibitory peptides from $\beta$-casein, f84-86 which corresponds to Val-Pro-Pro, and f74-76 which corresponds to Ile-Pro-Pro, and one from $\kappa$-casein, f108-110 which corresponds to Ile-ProPro, were purified from "Calpis", a Japanese soft drink made from bovine skim milk fermented by Lactobacillus helveticus and Saccharomyces cerevisiae (Nakamura et al., 1995). Those two tripeptides have been also found in casein hydrolysates produced by extracellular proteinase of L. helveticus CP790, and in milk inoculated with L. helveticus (Yamamoto, Akino, \& Takano, 1994a,b). In a placebo-controlled study, the blood pressure of hypertensive patients decreased significantly after 4-8 weeks of daily ingestion of $95 \mathrm{~mL}$ of sour milk containing such two tripeptides (Hata, Yamamoto, Ohni, Nakajima, \& Nakamura, 1996). 
A hypertensive dipeptide from a yoghurt-like product fermented by $L$. helveticus CPN4 containing the sequence Tyr-Pro was identified by Yamamoto, Maeno, and Takano (1999); it is found within $\alpha_{\mathrm{s} 1^{-}}$, $\beta$ - and $\kappa$-casein primary structures. The synthetic peptide yielded significant antihypertensive activity from 2 to $8 \mathrm{~h}$ after oral administration of $1 \mathrm{mg}$ of peptide per $\mathrm{kg}$ of body weight of spontaneously hypertensive rats, and this effect was further proven to be highly dependent on the peptide dosage; however, the peptide possessed a low inhibitory activity against angiotensin I-converting enzyme (Yamamoto et al., 1999).

The antihypertensive activity of casein-enriched milk, unfermented or fermented by L. helveticus, was evaluated by Leclerc, Gauthier, Bachelard, Sature, and Roy (2002); in the former situation, a significant reduction of blood pressure occurred, whereas the antihypertensive activity measured in the latter case could be explained by the release of ACE-inhibitory peptides from caseins during the digestion process.

Several bioactive peptides with ACE-inhibitory activity have also been found in cheese; their appearance is influenced by proteolysis, but only to a certain degree. An $\alpha_{\mathrm{s} 1}$-casein-derived antihypertensive peptide isolated from Parmesan cheese by 6 months of ripening could not be found after 15 months (Addeo et al., 1992). Accordingly, the antihypertensive activity found in long-ripened Gouda cheese was half that found in its medium-aged counterpart (Meisel, Goepfert, \& Günther, 1997). Partially consistent with these findings are those reported by Gómez-Ruiz, Ramos, and Recio (2002), when studying the ACE-inhibitory peptides in Manchego cheese manufactured with various starter cultures; the anti-hypertensive activity decreased within the first 4 months, was maximum by 8 months of ripening and decreased again towards 12 months. The protein fragments responsible for such activity were mainly low-molecular-weight peptides; a specific interest arose regarding f199-204 from $\beta$-casein and f102-109 from $\alpha_{\mathrm{s} 1}$-casein. Peptides isolated from Italian cheeses, namely Italico and Gorgonzola, were also found inhibitory of ACE activity (Smacchi \& Gobbeti, 1998). Following isolation from Gouda cheese, Saito, Nakamura, Kitazawa, Kawai, and Itoh (2000) analysed the structure of the antihypertensive features of a few peptides, and concluded that the strongest depressive effect on the systolic blood pressure and the highest ACE-inhibitory capacity is associated to peptides found in 8-months-old cheese.

Several new oligopeptides were identified after extraction, semi-quantification and fast on-line identification by HPLC-MS of samples of Grana Padano cheese. Some of them contained bioactive sequences showing potential biological activity (Sforza, Ferroni, Galaverna, Dossena, \& Marchelli, 2003).
A new type of ripened, low-fat cheese called "Festivo" was manufactured with classical starter cultures, in combination with $L$. acidophilus and bifidobacteria. Such a novel cheese possesses multifactorial health effects; it contains several beneficial components, e.g. bioactive peptides with potential antihypertensive effects, probiotics, conjugated linoleic acid and bioavailable calcium (Ryhänen, Pihlanto-Leppälä, \& Pahkala, 2001). Conversely, cheeses characterized by low levels of proteolysis, viz. Quark, exhibit low ACE-inhibitory capacity (Meisel et al., 1997).

As already mentioned, some peptides may contain several different bioactivities; studies encompassing purification and identification of potentially bioactive peptides from enzyme-modified cheese (EMC) (Haileselassie, Lee, \& Gibbs, 1999) showed that $\beta$-casomorphin, as well as other hydrophobic peptides released by Neutrase ${ }^{\circledR}$, might serve as precursors for antihypertensive peptides; this realization suggests that EMC may be an alternative vehicle for production of that class of compounds.

The ACE-inhibitory peptides derived from dairy products are not as potent as the drugs commonly used for hypertension treatment; however, those products that hold a moderate bioactivity behave intrinsically (and naturally) as functional foods, so they can easily be included in the daily diet (Meisel et al., 1997).

\section{Effects on the nervous system}

It is a common belief that falling asleep is easier after drinking a glass of milk in the evening, and that babies are soothed after breast or bottle feeding. Recent studies have provided evidence that peptides exist in dairy products which play an active role in the nervous system; known as opioid peptides, they can have agonistic or antagonistic activities (Table 3).

\section{Opioid peptides}

Located in the nervous endocrine (and also in the immune) system, as well as in the intestinal tract of mammals, opioid receptors (of the $\mu$-, $\delta$ - and $\kappa$-type) interact with endogenous or exogenous ligands. The former, called "typical" opioid peptides, e.g. enkephalin, endorphin and dynorphin, are derived from the precursor molecules proopiomelanocortin, proenkephalin and prodynorphin, respectively, and all share the typical N-terminal sequence Tyr-Gly-Gly-Phe. The latter, or "atypical" opioid peptides, have agonistic (exorphins, or formons - "food hormones") or antagonistic (casoxins) activities, and are characterized by distinct $\mathrm{N}$-terminal sequences. The common structural feature of endogenous and exogenous opioid peptides (except $\alpha$-casein opioids) is the presence of a Tyr residue 
Table 3

Opioid peptide sequences in the primary structure of caseins

\begin{tabular}{|c|c|c|c|}
\hline Casein type & Peptide sequence & Amino-acid segment & References \\
\hline & Agonistic peptide & & \\
\hline \multirow[t]{3}{*}{$\alpha_{\mathrm{s} 1}$ (bovine) } & $90-95$ & RYLGYL & Loukas et al. (1983) \\
\hline & $90-96$ & RYLGYLE & Loukas et al. (1983) \\
\hline & $91-95$ & YLGYL & Loukas et al. (1983) \\
\hline$\beta$ (human) & $41-44$ & YPSFQ & Fiat et al. (1993) \\
\hline \multirow[t]{2}{*}{$\gamma($ casein $)$} & $114-121$ & YPVEPFTE & Perpetuo et al. (2003) \\
\hline & Antagonistic pept & & \\
\hline \multirow[t]{4}{*}{$\kappa$ (bovine) } & $35-41$ & YPSYGLN & Xu (1998) \\
\hline & $58-61$ & YPYY & Xu (1998) \\
\hline & $25-34$ & YIPIQYVLSR & Xu (1998) \\
\hline & $158-164$ & EINTVQV & Xu (1998) \\
\hline
\end{tabular}

at the $\mathrm{N}$-terminus, coupled with the presence of another aromatic residue, e.g. Phe or Tyr, in the third or fourth position. This is an important structural feature, that ensures fitting into the binding site of opioid receptors; furthermore, the negative potential, localized in the vicinity of the phenolic hydroxyl group of tyrosine, seems to be essential for opioid activity - absence of bioactivity was indeed noticed when no tyrosine residue exists (Meisel, 1998).

Several authors have compiled information regarding opioid receptor ligands derived from food proteins, especially milk caseins (Teschemacher, 2003; Teschemacher, Koch, \& Brantl, 1997), and different opinions arised concerning the nature of the ligand-receptor interaction; hence, suitability of models for the determination of bioactive conformation of peptide ligands active towards $\mu$-opioid receptors have been discussed (Gentilucci \& Tolomelli, 2004).

The major and the first opioid peptides discovered are the so-called $\beta$-casomorphins (Brantl, Teschemacher, Henschen, \& Lottspeich, 1979), which are fragments of $\beta$-casein between the 60 th and the 70th residues, mainly f60-63, f60-64, f60-65, f60-66 and f60-70 (Smacchi \& Gobbettti, 2000); these peptides were characterized as $\mu$-type ligands (Teschemacher \& Brantl, 1994). Longobardo et al. (2000) reported that replacement of Phe in position 3 of two analogues of bovine $\beta$-casomorphin-7 and -5 by a $\beta$-homo-Phe enhanced the $\mu$-type opioid receptor affinity as compared to the natural peptides, by 5- and 2-fold, respectively; the most potent is the pentapeptide $\beta$-casein f60-64 (Fiat et al., 1993). A similar amino-acid sequence appears in $\beta$-casein from sheep milk (Richardson \& Mercier, 1979) and water buffalo milk (Petrilli, Addeo, Chianese, 1983). The sequence f41-44 from human milk $\beta$-casein was also claimed to be an opioid peptide, called $\beta$-casomorphin, holding agonistic activity (Fiat et al., 1993).
Three $\alpha_{\mathrm{s}}$-casein-derived exorphins, which typically correspond to bovine $\alpha_{\mathrm{s} 1}$-casein f90-95, f90-96 and f91-96, were found to be $\delta$-selective receptor ligands (Loukas, Varoucha, Zioudrou, Streaty, \& Klee, 1983).

More rencently, Perpetuo et al. (2003) reported a new peptide from $\gamma$-casein, Tyr-Pro-Val-Glu-Pro-Phe-ThrGlu, possessing in vitro opiate-like activity, which was generated by tryptic hydrolysis of casein.

Opioid peptides from milk can be obtained in vitro by proteolysis of bovine $\alpha_{\mathrm{s}^{-}}, \beta$ - and $\kappa$-caseins (PihlantoLeppälä, Antila, Mantsala, \& Hellman, 1994). Sequential digestion brought about by pepsin and trypsin increases the overall degree of proteolysis, which generates hydrolysates with stronger antimicrobial or antihypertensive activities than a single enzyme treatment (Pihlanto-Leppälä et al., 1998; Pihlanto-Leppälä, Marnila, Hubert, Rokka, \& Korhonen, 1999).

Studies in vivo have also been performed with opioid agonist peptides. Ermisch, Ruhle, Neubert, Hartrodt, and Landgraf (1983) have shown that, following intracarotid injection of $\left[{ }^{3} \mathrm{H}\right] \beta$-casomorphin- 5 in rats, this compound accumulated to a relatively high degree in the areas free of blood-brain barrier. Higher amounts of $\beta$-casomorphin-7 were also encountered in blood from newborn calves, under the form of a precursor (Fiat et al., 1993).

Meisel and Frister (1989) detected $\beta$-casomorphins in the intestinal chyme of minipigs, as well as in the small intestine of humans after ingestion of cow's milk (Svedberg, de Haas, Leimenstoll, Paul, \& Teschemacher, 1985). Since their absorption in the gut has not been reported to date, it is generally accepted that physiological influences are restricted to the gastrointestinal tract, where they may modulate gastrointestinal function, intestinal transit, amino-acid uptake and water balance. As soon as peptides enter the blood stream, they are believed to be quickly hydrolysed (Meisel, 
1997). On the other hand, $\beta$-casein-derived peptides may pass through the intestinal mucosa in neonates via passive transport, so babies may become calm and sleepy (Sturner \& Chang, 1988). In pregnant or lactating women, the mammary tissue is also permeable to $\beta$-casomorphin (Clare \& Swaisgood, 2000). Chabance et al. (1998) showed that many peptides from $\alpha_{\mathrm{s} 1^{-}}, \beta-, \kappa-$ casein and $\kappa$-caseinomacropeptide exist in the stomach of adults following consumption of milk or yoghurt, and some fragments of casein were also found in the duodenum. Moreover, the $\kappa$-caseinoglycopeptide and the $N$-terminal peptide of $\alpha_{\mathrm{s} 1}$-casein were shown to be absorbed, and were accordingly detected in the plasma.

Exorphins exhibit pharmacological properties similar to opium (morphine), and exert naloxone-inhibitable activities (Meisel \& Schlimme, 1990); they also induce apnea and irregular breathing, modulate sleep patterns, stimulate pancreatic insulin and gastrointestinal somatostatin release, modulate animal behaviour, stimulate intestinal absorption of electrolytes and water, modulate intestinal motility, and stimulate food intake by modifying the endocrine activity of the pancreas, hence causing an increase of insulin output (Xu, 1998). Recently, Sun et al. (2003) reviewed novel findings concerning the possible association between $\beta$-casomorphin and apnea in sudden infant death syndrome.

The $\beta$-casomorphin immunoreactive material was first identified by Hamel, Kielwein, and Teschmacher (1985) in cow's milk, that had been incubated with various bacterial species including lactic acid bacteria. Matar and Goulet (1996) produced fermented milk enriched with the (opioid) $\beta$-casomorphin 1-4 (f60-63) using a mutant strain of $L$. helveticus that lacks X-prolyldipeptidyl-aminopeptidase activity. In cheese, $\beta$-casomorphins are further hydrolysed in a gradual manner via the proteolytic enzymes of Lactococcus lactis subsp. cremoris during ripening; this process is strongly dependent on $\mathrm{pH}$ and salt concentration prevailing in that dairy product (Muehlenkamp \& Warthesen, 1996).

Opioid antagonists are those peptides that suppress the agonist activity of enkephalin; known as casoxins, they have been found in both bovine and human $\kappa$ casein, as well as in $\alpha_{\mathrm{s} 1}$-casein (Chiba, Tani, \& Yoshikawa, 1989; Yoshikawa et al., 1994). Two bovine casoxins are opioid receptor ligands of the $\mu$-type, with relatively low antagonistic potency as compared with naloxone (Meisel, 1998). Casoxins A and B correspond to amino-acid sequences within bovine $\kappa$-casein; casoxin A corresponds to f35-41 of $\kappa$-casein (i.e. Tyr-Pro-SerTyr-Gly-Leu-Asn), whereas casoxin B is accounted for by f58-61 of $\kappa$-casein (i.e. Tyr-Pro-Tyr-Tyr). Casoxin C is an opioid antagonist obtained from tryptic digests of bovine $\kappa$-casein; its sequence corresponds to f25-34 (i.e. Tyr-Ile-Pro-Ile-Gln-Tyr-Val-Leu-Ser-Arg), and possesses the highest biological potency (Xu, 1998). Casoxin D was generated from $\alpha_{\mathrm{s} 1}$-casein (Clare \& Swaisgood, 2000). Some casoxins were modified by methoxylation during the process of isolation and purification; they were proven to be more active than the corresponding C-terminal, non-methoxylated $\kappa$-casein fragment (Schlimme \& Meisel, 1995).

\section{Effects on the immune system}

The systems involved in the human body's defense against invaders are rather complex; diet is known to play an important role therein. Research concerning the role of functional peptides in this field is quite recent, but it already seems very promising. The two main activities are the immunomodulatory one (i.e. stimulation of the immune system) (Table 4) and the antimicrobial one (i.e. inhibition of pathogenic bacteria) (Table 5).

\section{Immunomodulating peptides}

Breast feeding facilitates physical transmission of passive immunity via a number of multifunctional factors, which have a direct effect on the neonate's resistance to bacterial and viral infections; caseins are included among these factors. In fact, during enzymatic

Table 4

Immunomodulating peptide sequences in the primary structure of caseins

\begin{tabular}{lcll}
\hline Casein type & Peptide sequence & Amino-acid segment & References \\
\hline$\alpha_{\mathrm{s} 1}$ (bovine) & $1-23$ & RPKHPIKHQGLPQEVLNENLLRF & Minkiewicz et al. (2000) \\
& $194-199$ & TTMPLW & Migliore-Samour and Jollès (1988); Parker et al. (1984) \\
$\alpha_{\mathrm{s} 2}$ (bovine) & $1-32$ & KNTMEHVSSSEESIISQETYKQEKNMAINPSK & Hata et al. (1999) \\
$\beta$ (bovine) & $1-28$ & RELEELNVPGEIVESLSSSEESITRINK & Hata et al. (1999) \\
& $63-68$ & PGPIPN & Migliore-Samour and Jollès (1988); Parker et al. (1984) \\
& $191-193$ & LLY & Migliore-Samour and Jollès (1988); Parker et al. (1984) \\
& $193-209$ & LLYQEPVLGPVRGPFPIIV & Minkiewicz et al. (2000) \\
$\beta$ (human) & $54-59$ & VEPIPY & Parker et al. (1984) \\
\hline
\end{tabular}


Table 5

Antimicrobial peptide sequences in the primary structure of caseins

\begin{tabular}{lcll}
\hline Casein type & Peptide sequence & Amino-acid segment & References \\
\hline$\alpha_{\mathrm{s} 1}$ (bovine) & $1-23$ & RPKHPIKHQGLPQEVLNENLLRF & Lahov and Regelson (1996) \\
$\alpha_{\mathrm{s} 2}$ (bovine) & $164-179$ & LKKISQRYQKFALPQY & Recio and Visser (1999) \\
& $165-203$ & KKISQRYQKFALPQYLKTVYQHQKAMKPWIQPKTKVIPY & Zucht et al. (1995) \\
& $183-207$ & VYQHQKAMKPWIQPKTKVIPYVRYL & Recio and Visser (1999) \\
$\beta$ (bovine) & $193-209$ & YQEPVLGPVRGPFPIIV & Sandre et al. (2001) \\
\hline
\end{tabular}

digestion of human and bovine milk caseins, peptides with immunomodulating capacities are released. Jollès et al. (1981) were the first to report that extracts of trypsin-hydrolysed human milk possess immunostimulating activity; in particular, the hexapeptide Val-GluPro-Ile-Pro-Tyr, corresponding to f54-59 of human milk $\beta$-casein, was isolated from its tryptic hydrolysate (Parker et al., 1984) and proven to account for such an activity - it is noteworthy that this peptide represents the C-terminal part of $\beta$-casomorphin-11. Several other peptides were later isolated, namely f63-68 and f191-193 from bovine $\beta$-casein, and f194-199 from bovine $\alpha_{\mathrm{s} 1}$-casein (Migliore-Samour \& Jollès, 1988; Parker et al., 1984). All the aforementioned peptides stimulate phagocytic activity of murine and human macrophages in vitro, and exert a protective effect against Klebsiella pneumoniae infection in mice in vivo (Migliore-Samour, Floch, \& Jollès, 1989). More recently, the $\mathrm{pH}$ 4.6-soluble products from the hydrolysis of whole bovine casein by chymosin encompassed peptides possessing immunomodulatory activity, i.e. $\alpha_{\mathrm{s} 1}$-casein f1-23 and $\beta$-casein f193-209 (Minkiewicz, Slangen, Dziuba, Visser, \& Mioduszewska, 2000). A tripeptide from $\kappa$-casein increased significantly the proliferation of human peripheral blood lymphocytes in vivo (Kayser \& Meisel, 1996), whereas the C-terminal sequence of bovine $\beta$-casein (f193-209), containing $\beta$-casokinin-10, induced similar results in rats (Coste et al., 1992).

Bioactive peptides present in yoghurt actually decreased cell proliferation with IEC-6 or Caco- 2 cells, which may explain, at least partially, why consumption of yoghurt has been associated with a reduced incidence of colon cancer (Ganjam, Thornton, Marshall, \& MacDonald, 1997). Ru zhen, a product containing bioactive protein and colostral polypeptides, was proved to possess immunomodulatory activity and the potential to improve resistance to disease (Zhang, Hou, \& Su, 1998). Meisel and Günther (1998) reported that milk proteins are precursors of peptides that modulate the activity of human cells, after having investigated the modulating activity of peptides corresponding to bioactive sequences of casein and a lyophilised extract of Gouda cheese.
A commercially available caseinophosphopeptide preparation CPP-III, consisting mainly of f1-32 of bovine $\alpha_{\mathrm{s} 2}$-casein and f1-28 of $\beta$-casein, enhances the proliferative response induced by lipopolysaccharide, phytohaemagglutinin and concavalin A stimulation, and immunoglobulin production in mouse spleen cell cultures; this immunostimulating activity was attributed to the $o$-phospho- $l$-serine residue, hence suggesting that such a bioactivity is relatively stable to proteinase action in the intestinal tract (Hata, Ueda, \& Otani, 1999). Studies focusing on the effects of CPP-III on serum and intestinal immunoglobulin $\mathrm{G}$ and immunoglobulin $\mathrm{A}$ in mice proved that oral use of caseinophosphopeptide is beneficial toward enhancement of the mucosal immunity (Otani, Kihara, \& Minkyu, 2000).

Matar, Valdez, Medina, Rachid, and Perdigon (2001) studied the effects of milks fermented by L. helveticus and its non-proteolytic variant on mucosal and tumoral immunity, via oral administration of milk to mice $(3 \mathrm{~mL}$ per mouse per day) for 3,5 and 7 days. Lactic acid bacteria apparently show important implications upon modulation of the host's immune response, mainly its cellular one, because they are responsible for release of bioactive peptides. Three fractions from the aforementioned fermented milk were then isolated and fed to mice for various periods (2, 5 and 7 days), and the effect thereof on their tumoral immune system and on fibrosarcoma growth was duly analysed (LeBlanc, Matar, Valdez, LeBlanc, \& Perdigón, 2002). The mechanism by which lactic acid bacteria enhance the immune system is not yet clear, but it is accepted that bioactive compounds released in fermented milks contribute to the immunoenhancing and antitumour properties of these dairy products.

Supplementation of infant formulae with appropriate milk proteins, viz. caseinomacropeptide, may help to promote growth of a host-friendly colonic microflora, mainly bifidobacteria or lactobacilli, and may help to overcome some enteric infections (Bruck, Graverholt, \& Gibson, 2003; Bruck et al., 2003).

Nowadays, the mechanism, structure and activity by which milk protein-derived peptides exert their immunomodulatory effect is still questionable. However, the Arg residue at the $\mathrm{N}$ - or C-terminal region of a peptide 
has been suggested to be the leading motif recognizable by specific surface membrane receptors; in this context, it is worth noting that the immunomodulatory ACEinhibitor peptide $\beta$-casokinin-10 (among other ACEinhibitory peptides) has Arg in its C-terminus. Opioid peptides are also thought to affect the immunoreactivity of lymphocytes via opiate $\mu$-receptors, which, for endorphins, are present on T-lymphocytes and human phagocytic leucocytes (Meisel, 1998).

\section{Antimicrobial peptides}

In vitro inhibition of growth of pathogenic strains occurs in the presence of $\alpha_{\mathrm{s} 2}$-casein or lactoferricin fragments (Tomita, Takase, Bellami, \& Shimamura, 1994; Zucht, Raida, Adermann, Magert, \& Forssman, 1995). Caseicidin, obtained by chymosin-mediated digestion of casein at neutral $\mathrm{pH}$, was among the first defence peptides actually purified - it exhibited activity against Staphylococcus spp., Sarcina spp., Bacillus subtilis, Diplococcus pneumoniae and Streptococcus pyogenes (Lahov \& Regelson, 1996). A cationic fragment from $\alpha_{\mathrm{s} 2}$-casein, f165-203, known as casocidin-I, can inhibit growth of Escherichia coli and S. carnosus (Zucht et al., 1995). Two other peptides were meanwhile isolated from a peptic hydrolysate of $\alpha_{\mathrm{s} 2}$-casein, namely f183-207 and f164-179; the former exhibited higher antimicrobial activity than the latter, although both possessed comparable hemolytic effects (Recio \& Visser, 1999). Lactoferricin, or f17-41 from lactoferrin produced by enzymatic cleavage brought about by pepsin, was shown to possess more potent bactericidal properties than the undigested, iron-binding glycoprotein present in most biological fluids of mammals, including milk (Meisel, 1998).

The other fragment of $\alpha_{\mathrm{s} 1}$-casein, viz. f1-23, known as isracidin, has demonstrated antibiotic-type activity in vivo versus $S$. aureus and Candida albicans; it can protect sheep and cows against mastitis (Lahov \& Regelson, 1996). Fragments of human $\beta$-casein have also a protective effect against Klebsiella pneumoniae in mice (Migliore-Samour et al., 1989). The immunomodulatory peptide derived from bovine $\beta$-casein, viz. f193-209, was shown to enhance the antimicrobial activity of mouse macrophages, which had been obtained either from germ-free or from human floraassociated mice, without proinflammatory effects (Sandre et al., 2001).

All these results pertaining to animals have been obtained in vivo by injecting peptides therein; at present, no studies are yet available that provide evidence for their putative effect when ingested.

\section{Effects on the nutrition system}

Some peptides are able to sequester calcium and other minerals, hence acting as biocarriers - they are called phosphopeptides (Table 6); glycomacropeptide (GMP) may also exhibit a number of nutritional features; both are discussed below.

\section{Caseinophosphopeptides}

The term phosphopeptide was pioneered by Mellander (1950), and it means a casein-derived phosphorylated peptide which enhances vitamin D-independent bone calcification in rachitic infants. Chabance et al. (1998) have proven the occurrence of caseinophosphopeptides (CPPs) in the stomach and duodenum following milk ingestion. CPPs have also been found after in vitro and/or in vivo digestion of $\alpha_{\mathrm{s}^{-}}, \alpha_{\mathrm{s} 2^{-}}$or $\beta$-casein (Kitts, 1994); f43-58, f45-55, f59-79, f66-74 and f106-119 from $\alpha_{\mathrm{s} 1}$-casein, f2-21, f46-70, f55-75, f126-136 and f138-149 from $\alpha_{\mathrm{s} 2}$-casein, and f1-25, f1-28 and $\mathrm{f} 2-28$ from $\beta$-casein have been reported in this

Table 6

Caseinophosphopeptide sequences in the primary structure of caseins

\begin{tabular}{lcll}
\hline Casein type & Peptide sequence & Amino-acid segment & References \\
\hline$\alpha_{\mathrm{s} 1}$ (bovine) & $43-58$ & DIGSESTEDQAMEDIK & Smacchi and Gobbetti (2000) \\
& $45-55$ & GSESTEDQAME & Smacchi and Gobbetti (2000) \\
& $59-79$ & QMEAESISSSEEIVPNSVEQK & Smacchi and Gobbetti (2000) \\
& $66-74$ & SSSEEIVPN & Smacchi and Gobbetti (2000) \\
& $106-119$ & VPQLEIVPNSAEER & \\
$\alpha_{\mathrm{s} 2}$ (bovine) & & & \\
& $2-21$ & NTMEHVSSSEESIISQETYK & Smacchi and Gobbetti (2000) \\
& $46-70$ & NANEEEYSIGSSSEESAEVATEEVK & Smacchi and Gobbetti (2000) \\
& $55-75$ & GSSSEESAEVATEEVKITVDD & Smacchi and Gobbetti (2000) \\
& $126-136$ & SQLSTSEENSK & Smacchi and Gobbetti (2000) \\
$\beta$ (bovine) & $138-149$ & TVDMESTEVFTK & \\
& $1-25$ & RELEbetti (2000) \\
& $1-28$ & RELEELNVPGEIVESLSSSEESITRINK & Smacchi and Gobbetti (2000) \\
& $2-28$ & ELEELNVPGEIVESLSSSEESITRINK & Smacchi and Gobbetti (2000) \\
& & & Smacchi and Gobbetti (2000) \\
\hline
\end{tabular}


particular (Smacchi \& Gobbetti, 2000). Certain CPPs were for the first time detected in ileostomy fluid by Meisel et al. (2003), which confirms the ability of such peptides to survive gastrointestinal passage to the human distal ileum. In addition to their presence in whole milk, CPPs have also been claimed to be released by proteolytic enzymes of lactic acid bacteria during ripening of such cooked curd cheeses as Grana Padano (Pellegrino et al., 1997) and Comté (Roudot-Algaron, le Bars, Kerhoas, Einhorn, \& Gripon, 1994).

Recently, Meisel and FitzGerald (2003) have reviewed the structural features and physiological potential of milk-protein-derived caseinophosphopeptides, which were also shown to exert cytomodulatory effects.

The phosphate residues, corresponding to ca. $30 \%$ of the phosphorus content in milk, are present as monoesters of Ser and occur mainly in clusters; most CPPs share a common feature, i.e. they are constituted by a sequence of three phosphoseryl residues, followed by two glutamic acid residues, viz. SerP-SerP-SerP-Glu-Glu (Meisel, Frister, \& Schlimme, 1989; Meisel, 1997).

The high concentration of negative charges of phosphate peptides makes them resistant to further proteolysis (Clare \& Swaisgood, 2000; Reynolds, Riley, \& Adamson, 1994; Meisel \& Schlimme, 1990; Hirayama, Toyota, Yamaguchi, Hidaka, \& Naito, 1992; Kasai, Honda, \& Kiriyama, 1992; Kasai, Iwasaki, Tanaka, \& Kiriyama, 1995; FitzGerald, 1998).

Furthermore, the negatively charged side chains, in particular the phosphate groups, of those amino acids represent the binding sites for minerals (Meisel, 1998); CPPs have been shown to bind to such macroelements as $\mathrm{Ca}, \mathrm{Mg}$ and $\mathrm{Fe}$, as well as to such oligoelements as $\mathrm{Zn}, \mathrm{Ba}, \mathrm{Cr}, \mathrm{Ni}, \mathrm{Co}$ and Se. However, the Ca-binding activity of the phosphopeptide fractions of casein can be different - which may be attributed to the influence of further amino acids around the phosphorylated binding sites (Meisel, 1998).

Iron deficiency, a major worldwide nutritional problem, can be reduced by CPPs; in fact, binding of Fe to phosphopeptides prevents formation of high-molecularweight ferric hydroxides, which are poorly absorbed. In vitro studies with rats (Ait-Oukhatar et al., 1999) have demonstrated that $\mathrm{Fe}$ bound to the phosphoserine residues of low-molecular-weight CPPs, namely $\beta$-casein f1-25, improved their ability to treat anaemia and restore $\mathrm{Fe}$ storage tissues, when compared with $\mathrm{Fe}$ bound to whole casein and inorganic salts. Further studies in vivo (Ait-Oukhatar et al., 2002), using radiolabelled iron, assessed $\mathrm{Fe}$ absorption and uptake by tissues involved in $\mathrm{Fe}$ metabolism and storage; the metabolism of $\beta$-casein $\mathrm{f} 1-25^{59}[\mathrm{Fe}]$, added to cows' milk was studied in young women - absorption thereof was not significantly above that of ferrous sulfate, but a significantly higher, transient tissue uptake was noticed that vanished by 14 days (hence suggesting that iron was used for metabolic purposes).

Zinc absorption can also be enhanced if that metal is bound to CCPs, namely $\beta$-casein $\mathrm{f} 1-25$; moreover, its inhibition by such other nutrients as $\mathrm{Fe}$ is prevented (Peres et al., 1998). An increase in $\mathrm{Ca}$ and $\mathrm{Zn}$ absorption was noticed after CPP incorporation into rice-based infant food, during a human feeding trial (Meisel \& Bockelmann, 1999; Hansen, Sandstöm, Jensen, \& Sörensen, 1997).

Milk and dairy products provide plenty of $\mathrm{Ca}^{2+}$, which can form soluble complexes with those phosphopeptides, thus avoiding $\mathrm{Ca}$ phosphate precipitation (Sato, Naguchi, \& Naito, 1986; Berrocal et al., 1989), and enhancing intestinal absorption of $\mathrm{Ca}$ and retention thereof in the body (Mykkänen \& Wasserman, 1980; Sato et al., 1986). According to Meisel (1997), binding of $\mathrm{Ca}$ involves Ser-bound phosphate groups, as well as the free carboxyl groups of Glu; the hydrophobic tail protects this complex from further interactions, and hence prevents formation of insoluble calcium phosphate. Ferraretto, Signorile, Gravaghi, and Fiorilli (2001) found out that casein phophopeptides influence calcium uptake by cultured human intestinal HT-29 tumor cells. Chemically synthesized casein phosphopeptides $\beta$-casein (1-25)4P and $\alpha_{\mathrm{s} 1}-\mathrm{CN}(59-79) 5 \mathrm{P}$, carrying the characteristic "acid motif" $\operatorname{Ser}(\mathrm{P})-\operatorname{Ser}(\mathrm{P})-\operatorname{Ser}(\mathrm{P})$ Glu-Glu, were found to cause an increase of $\mathrm{Ca}^{2+}$ concentration due to influx of extracellular $\mathrm{Ca}^{2+}$, the effect being more pronounced with the $\beta$-casein-derived petide than with $\alpha_{\mathrm{s} 1}$-casein-derived one. Moreover, the CPP-promoting effect on calcium concentration was proven to depend on the structural conformation conferred by both the phosphorylated "acidic motif" and the preceding N-terminal portion (Ferraretto, Gravaghi, Fiorilli, \& Tettamanti, 2003).

It has been shown that Ca-binding phosphopeptides have anticariogenic effects via inhibition of caries lesion through recalcification of the dental enamel-hence, their application in the treatment of dental diseases has been proposed (Clare \& Swaisgood, 2000; Reynolds, 1987; Tirelli et al., 1997), namely as additives to toothpaste (Reynolds, 1994). The consumption of cheese has an anticariogenic effect as well; a significant correlation was found between the high content of casein in cheese and the caries-protective effect thereof (Pause \& Lembke, 1993). Moreover, anticariogenic activity has also been reported for phosphopeptides from eggs (viz. phosvitin and phosphophorin) (Reynolds, 1994; Tirelli et al., 1997).

Heating processes affect the bioavailability of CPPs; sterilization can induce dephosphorylation of phosphoseryl residues that occur in clusters, and formation of dehydroalanine from residues occupying isolated positions in the peptide chain (Meisel, Andersson, Buhl, Erbersdobler, \& Schlimme, 1991). 


\section{Glycomacropeptide}

The glycomacropeptide (GMP) is formed during the enzymatic cheesemaking process. Rennet or chymosin hydrolyses the peptide bond between residues 105 and 106 of $\kappa$-casein, and the resulting molecule, GMP, is eluted in the whey. This molecule contains residues 106-169 of $\kappa$-casein; the C-terminal portion of said molecule is more hydrophilic, as it contains the oligosaccharides that are O-linked to threonine and serine. The large GMP molecule cannot be absorbed as such, so it has to be broken down into smaller peptides before an effect on blood components arises. GMP is unique in its amino-acid composition - it lacks aromatic amino acids and is rich in branched chain ones.

Besides the various bioactivities displayed by GMP (or smaller peptides derived therefrom), which were already referred to above where appropriate, a number of beneficial effects upon the nutrition system can be claimed. El Salam, El-Shibiny, and Buchheim (1996) indicated that GMP might be useful for diets aimed at controling several liver diseases, in cases where branched chain amino acids appear to be used as a carbon source.

Stan, Ekimovskii, Aleinik, and Zhuravlev (1988) showed that pepsin hydrolysis produced several different peptides with distinct physiological activities. One of these is an opioid effect, and another is a satiety effect when administered to starving animals; the latter effect was similar to that exhibited following cholecystokinin injection.

A well-known disease in infants fed with whey proteinpredominant formulae is hyperthreoninemia. Sweet whey, containing not only whey proteins but also the threonine-rich GMP, is commonly used for the manufacture of those formulae. Rigo et al. (2001) tested an experimental formula based on acid whey without GMP, against a formula based on whey with GMP upon threonine metabolism; acid whey formulae are accordingly recommended for feeding preterm infants. Later on, Fanaro and Vigi (2002) emphasized that removal of GMP from whey is recommended towards the development of infant formulae closer to human milk.

Glycomacropeptide is also known to allow absorption of calcium, iron or zinc. Kelleher, Chatterton, Nielsen, and Lonnerdal (2003) studied GMP and $\alpha$-lactalbumin supplementation of infant formulae on the nutritional status in infant rhesus monkeys, and found that both increase zinc absorption - which may allow reduction of formula zinc concentrations and promote a plasma amino-acid pattern similar to that of breastfed infant monkeys, respectively.

\section{Conclusions}

There are four main physiological issues that caseinderived bioactive peptides can address: the cardiovas- cular system, the nervous system, the immune system and the nutrition system. Such bioactive peptides have been proven to possess antithrombotic, antihypertensive, opioid, immunomodulatory and antimicrobial activities. Casein-derived peptides have already met with interesting applications, both as dietary supplements in functional foods and as pharmaceutical preparations. However, whether bioactive peptides are beneficial and desirable as food constituents or as drugs is a matter that should be carefully examined on a caseto-case basis. Moreover, adverse effects associated with bioactive peptides should be carefully considered, namely if incorporated in functional food formulation at concentrations not attainable by ingestion of original milk products. The possibilities for designing new dietary products and natural drugs look promising. Future research should thus deepen existing knowledge of the molecular mechanisms underlying distinct bioactivities, and focus on the physiological functions of milkderived bioactive peptides.

\section{References}

Addeo, F., Chianese, L., Salzano, A., Sacchi, R., Cappuccio, U., Ferranti, P., \& Malorni, A. (1992). Characterization of the $12 \%$ trichloroacetic acid-insoluble oligopeptides of Parmigiano-Reggiano cheese. Journal of Dairy Research, 59(3), 401-411.

Ait-Oukhatar, N., Bouhallab, S., Arhan, P., Maubois, J. L., Drosdowsky, M., \& Bougle, D. (1999). Iron tissue storage and hemoglobin levels of deficient rats repleted with iron bound to the caseinophosphopeptide 1-25 of $\beta$-casein. Journal of Agricultural and Food Chemistry, 47(7), 2786-2790.

Ait-Oukhatar, N., Peres, J. M., Bouhallab, S., Neuville, D., Bureau, F., Bouvard, G., Arhan, P., \& Bougle, D. (2002). Bioavailability of caseinophosphopeptide-bound iron. Journal of Laboratory and Clinical Medicine, 140(4), 290-292.

Berrocal, R., Chanton, S., Juillerat, M. A., Pavillard, B., Scherz, J.-C., \& Jost, R. (1989). Tryptic phosphopeptides from whole casein. II. Physicochemical properties related to the solubilization of calcium. Journal of Dairy Research, 56(3), 335-341.

Brantl, V., Teschemacher, A., Henschen, A., \& Lottspeich, F. (1979). Novel opioid peptides derived from casein ( $\beta$-casomorphins). Hoppe Seyler's Zeitschrift fur Physiologische Chemie, 360(9), 1211-1216.

Bruck, W. M., Graverholt, G., \& Gibson, G. R. (2003). A two-stage continuous culture system to study the effect of suplemental $\alpha$ lactalbumin and glycomacropeptide on mixed cultures of human gut bacteria challenged with enteropathogenic Escherichia coli and Salmonella serotype typhimurium. Journal of Applied Microbiology, 95(1), 44-53.

Bruck, W. M., Kelleher, S. L., Gibson, G. R., Nielsen, K. E., Chatterton, D. E., \& Lonnerdal, B. (2003). rRNA probes used to quantify the effects of glycomacropeptide and $\alpha$-lactalbumin supplementation on the predominant groups of intestinal bacteria of infant rhesus monkeys challenged with enteropathogenic Escherichia coli. Journal of Pediatric Gastroenterology and Nutrition, 37(3), 273-280.

Chabance, B., Jollès, P., Izquierdo, C., Mazoyer, E., Francoual, C., Drouet, L., \& Fiat, A. M. (1995). Characterization of an antithrombotic peptide from $\kappa$-casein in new born plasma after milk ingestion. British Journal of Nutrition, 73(4), 583-590. 
Chabance, B., Marteau, P., Rambaud, J. C., Migliore-Samour, D., Boynard, M., Perrotin, P., Guillet, R., Jollès, P., \& Fiat, A. M. (1998). Casein peptide release and passage to the blood in humans during digestion of milk and yogurt. Biochimie, 80(2), 155-165.

Chiba, H., Tani, F., \& Yoshikawa, M. (1989). Opioid antagonist peptides derived from $\kappa$-casein. Journal of Dairy Research, 56(3), 363-366.

Clare, D. A., Catignani, G. L., \& Swaisgood, H. E. (2003). Biodefense properties of milk: The role of antimicrobial proteins and peptides. Current Pharmaceutical Design, 9(16), 1239-1255.

Clare, D. A., \& Swaisgood, H. E. (2000). Bioactive milk peptides: A prospectus. Journal of Dairy Science, 83(6), 1187-1195.

Coste, M., Rochet, V., Leonil, J., Molle, D., Bouhallab, S., \& Tome, D. (1992). Identification of C-terminal peptides from bovine $\beta$-casein that enhance proliferation of rat lymphocytes. Immunology Letters, 33(1), 41-46.

El-Salam, A., El-Shibiny, S., \& Buchheim, W. (1996). Characteristics and potential uses of the casein macropeptide. International Dairy Journal, 6(4), 327-341.

Ermisch, A., Ruhle, H. J., Neubert, K., Hartrodt, B., \& Landgraf, R. (1983). On the blood-brain barrier to peptides: $\left[{ }^{3} \mathrm{H}\right] \beta$-casomorphin5 uptake by eighteen brain regions in vivo. Journal of Neurochemistry, 41(5), 1229-1233.

Fanaro, S., \& Vigi, V. (2002). [Protein quality and quantity in infant formulas. A critical look]. Minerva Pediatrica, 54(3), 203-209.

Ferraretto, A., Signorile, A., Gravaghi, C., \& Fiorilli, A. (2001). Casein phosphopeptides influence calcium uptake by cultured human intestinal HT-29 tumor cells. Journal of Nutrition, 131(6), 1655-1661.

Ferraretto, A., Gravaghi, C., Fiorilli, A., \& Tettamanti, G. (2003). Casein-derived bioactive phosphopeptides: Role of phosphorylation and primary structure in promoting calcium uptake by Ht-29 tumor cells. FEBS Letters, 551(1-3), 92-98.

Fiat, A. M., \& Jollès, P. (1989). Caseins of various origins and biologically active casein peptides and oligosaccharides: Structural and physiological aspects. Molecular and Cellular Biochemistry, 87(1), 5-30.

Fiat, A-M., Migliore, D., \& Jollès, P. (1993). Biologically active peptides from milk proteins with emphasis on two examples concerning antithrombotic and immunostimulating activities. Journal of Dairy Science, 76(1), 301-310.

FitzGerald, R. J. (1998). Potential uses of caseinophosphopeptides. International Dairy Journal, 8(5/6), 451-457.

Florisa, R., Recio, I., Berkhout, B., \& Visser, S. (2003). Antibacterial and antivirial effects of milk proteins and derivatives thereof. Current Pharmaceutical Design, 9(16), 1257-1275.

Ganjam, L. S., Thornton, W. H., Marshall, R. T., \& MacDonald, R. S. (1997). Antiproliferative effects of yogurt fractions obtained by membrane dialysis on cultured mammalian intestinal cells. Journal of Dairy Science, 80(10), 2325-2329.

Gentilucci, L., \& Tolomelli, A. (2004). Recent advances in the investigation of the bioactive conformation of peptides active at the $\mu$-opioid receptor. Conformational analysis of endomorphins. Current Topics in Medicinal Chemistry, 4(1), 105-121.

Gómez-Ruiz, J. A., Ramos, M., \& Recio, I. (2002). Angiotensinconverting enzyme-inhibitory peptides in Manchego cheeses manufactured with different starter cultures. International Dairy Journal, 12(8), 697-706.

Haileselassie, S. S., Lee, B. H., \& Gibbs, B. F. (1999). Purification and identification of potentially bioactive peptides from enzymemodified cheese. Journal of Dairy Science, 82(8), 1612-1617.

Hamel, U., Kielwein, G., \& Teschmacher, H. (1985). $\beta$-Casomorphin immunoreactive materials in cow's milk incubated with various bacterial species. Journal of Dairy Research, 52(1), 139-148.

Hansen, M., Sandstöm, B., Jensen, M., \& Sörensen, S. S. (1997). Casein phosphopeptides improve zinc and calcium absorption from rice-based but not from whole grain infant cereal. Journal of Pediatric Gastroenterology and Nutrition, 24(1), 56-62.

Hata, I., Ueda, J., \& Otani, H. (1999). Immunostimulatory action of a commercially available casein phosphopeptide preparation, CPPIII, in cell cultures. Milchwissenschaft, 54(1), 3-7.

Hata, H., Yamamoto, M., Ohni, M., Nakajima, K., \& Nakamura, Y. (1996). A placebo-controlled study of the effect of sour milk on blood pressure in hypertensive subjects. American Journal of Clinical Nutrition, 64(5), 767-771.

Hirayama, M., Toyota, K., Yamaguchi, G., Hidaka, H., \& Naito, H. (1992). HPLC analysis of commercial casein phosphopeptides (CPP). Bioscience, Biotechnology and Biochemistry, 56(7), $1126-1127$.

Holt, C. (1997). The milk salts and their interaction with casein. In P. F. Fox (Ed.), Advanced Dairy Chemistry (pp. 233-256). London: Chapman \& Hall.

Janecka, A., Fichna, J., \& Janecki, T. (2004). Opioid receptors and their ligands. Current Topics in Medicinal Chemistry, 4(1), 1-17.

Jollès, P. (1975). Structural aspects of the milk clotting process. Comparative features with the blood clotting process. Molecular and Cellular Biochemistry, 7(2), 73-85.

Jollès, P., \& Henschen, A. (1982). Comparison between the clotting of blood and milk. Trends in Biochemical Science, 7, 325-328.

Jollès, P., Levy-Toledano, S., Fiat, A. M., Soria, C., Gillesen, D., Thomaidis, A., Dunn, F. W., \& Caen, J. (1986). Analogy between fibrinogen and casein: Effect of an undecapeptide isolated from $\kappa$ casein on platelet function. European Journal of Biochemistry, 158(2), 379-382.

Jollès, P., Loucheux-Lefèbvre, M. H., \& Henschen, A. (1978). Structural relatedness of $\kappa$-casein and fibrinogen $\gamma$-chain. Journal of Molecular Evolution, 11(4), 271-277.

Jollès, P., Parker, F., Floch, F., Migliore, D., Alliel, P., Zerial, A., \& Werner, G. H. (1981). Immunostimulating substances from human casein. Journal of Immunopharmacology, 3(3-4), 363-369.

Karaki, H., Dot, K., Sugano, S., Uchiwa, H., Sugai, R., Murakami, U., \& Takemoto, S. (1990). Antihypertensive effect of tryptic hydrolysate of milk casein in spontaneously hypertensive rats. Comparative Biochemistry and Physiology C, 96(2), 367-371.

Kasai, T., Honda, T., \& Kiriyama, S. (1992). Caseinophosphopeptides (CPP) in faeces of rats fed a casein diet. Bioscience, Biotechnology and Biochemistry, 56, 1150-1151.

Kasai, T., Iwasaki, R., Tanaka, M., \& Kiriyama, S. (1995). Caseinophosphopeptides (CPP) in faeces and contents in digestive tract of rats fed casein and CPP preparations. Bioscience, Biotechnology and Biochemistry, 59(1), 26-30.

Kayser, H., \& Meisel, H. (1996). Stimulation of human peripheral blood lymphocytes by bioactive peptides derived from bovine milk proteins. FEBS Letters, 383(1-2), 18-20.

Kelleher, S. L., Chatterton, D., Nielsen, K., \& Lonnerdal, B. (2003). Glycomacropeptide and $\alpha$-lactalbumin supplementation of infant formula affects growth and nutritional status in infant rhesus monkeys. The American Journal of Clinical Nutrition, 77(5), 1261-1268.

Kilara, A., \& Panyam, D. (2003). Peptides from milk proteins and their properties. Critical Reviews in Food Science and Nutrition, 43(6), 607-633.

Kitts, D. D., \& Weiler, K. (2003). Bioactive proteins and peptides from food sources. Applications of bioprocesses used in isolation and recovery. Current Pharmaceutical Design, 9(16), 1309-1323.

Kitts, D. (1994). Bioactive peptides in food: Identification and potential uses. Canadian Journal of Physiology and Pharmacology, 72(4), 423-434.

Kohmura, M., Nio, N., \& Ariyoshi, Y. (1990). Inhibition of angiotensin-converting enzyme by synthetic peptide fragments of human $\kappa$-casein. Agricultural and Biological Chemistry, 54(3), $835-836$. 
Kohmura, M., Nio, N., Kubo, K., Minoshima, Y., Munekata, E., \& Ariyoshi, Y. (1989). Inhibition of angiotensin-converting enzyme by synthetic peptide fragments of human $\beta$-casein. Agricultural and Biological Chemistry, 53(8), 2107-2114.

Korhonen, H., \& Pihlanto, A. (2003). Food-derived bioactive peptides - opportunites for designing future foods. Current Pharmaceutical Design, 9(16), 1297-1308.

LeBlanc, J. G., Matar, C., Valdez, J. C., LeBlanc, J., \& Perdigón, G. (2002). Immunomodulating effects of peptidic fractions issued from milk fermented with Lactobacillus helveticus. Journal of Dairy Science, 85(11), 2733-2742.

Lahov, E., \& Regelson, W. (1996). Antibacterial and immunostimulating casein-derived substances from milk: Caseicidin, isracidin peptides. Food and Chemical Toxicology, 34(1), 131-145.

Leclerc, P. L., Gauthier, S. F., Bachelard, H., Sature, M., \& Roy, D. (2002). Antihypertensive activity of casein-enriched milk fermented by Lactobacillus helveticus. International Dairy Journal, 12(12), 995-1004.

Longobardo, L., Melck, D., Siciliano, R., Santini, A., di Marzo, V., \& Cammarota, G. (2000). $\beta$-Casomorphin: Substitution of the phenylalanine with $\beta$-homo-phenylalanine increases the $\mu$-type opioid receptor activity. Bioorganic and Medicinal Chemistry Letters, 10(11), 1185-1188.

Lonnerdal, B. (2003). Nutritional and physiologic significance of human milk proteins. The American Journal of Clinical Nutrition, 77(6), 1537-1543.

Loukas, S., Varoucha, D., Zioudrou, C., Streaty, R. A., \& Klee, W. A. (1983). Opioid activities and structures of $\alpha$-casein-derived exorphins. Biochemistry, 22(19), 4567-4573.

Maeno, M., Yamamoto, N., \& Takano, T. (1996). Identification of an antihypertensive peptide from casein hydrolysate produced by a proteinase from Lactobacillus helveticus Cp790. Journal of Dairy Science, 79(8), 1316-1321.

Maruyama, S. H., Mitachi, H., Awaja, J., Kurono, M., Tomizaka, N., \& Suzuki, H. (1987a). Angiotensin I-converting enzyme inhibitor activity of the C-terminal hexapeptide of $\alpha_{\mathrm{s} 1}$-casein. Agricultural and Biological Chemistry, 51, 2557-2561.

Maruyama, S. H., Mitachi, H., Tanaka, H., Tomizuka, N., \& Suzuki, H. (1987b). Studies on the active site and antihypertensive activity of angiotensin I-converting enzyme inhibitors derived from casein. Agricultural and Biological Chemistry, 51, 1581-1586.

Maruyama, S., \& Suzuki, H. (1982). A peptide inhibitor of angiotensin I-converting enzyme in the tryptic hydrolysate of casein. Agricultural and Biological Chemistry, 46, 1393-1394.

Matar, C., \& Goulet, J. (1996). $\beta$-Casomorphin 4 milk fermented by a mutant of Lactobacillus helveticus. International Dairy Journal, 6(4), 383-397.

Matar, C., Valdez, J. C., Medina, M., Rachid, M., \& Perdigon, G. (2001). Immunomodulating effects of milks fermented by Lactobacillus helveticus and its non-proteolytic variant. Journal of Dairy Research, 68(4), 601-609.

Meisel, H. (1997). Biochemical properties of regulatory peptides derived from milk proteins. Biopolymers, 43(2), 119-128.

Meisel, H. (1998). Overview on milk protein-derived peptides. International Dairy Journal, 8(5/6), 363-373.

Meisel, H., Andersson, H. B., Buhl, K., Erbersdobler, H. F., \& Schlimme, E. (1991). Heat-induced changes in casein-derived phosphopeptides. Zeitschrift für Ernaehrungswissenschaft, 30(3), 227-232.

Meisel, H., \& Bockelmann, W. (1999). Bioactive peptides encrypted in milk proteins: Proteolytic activation and thropho-functional properties. Antoine van Leeuwenhoek, 76(1-4), 207-215.

Meisel, H., \& FitzGerald, R. J. (2003). Biofunctional peptides from milk proteins: Mineral binding and cytomodulatory effects. Current Pharmaceutical Design, 9(16), 1289-1295.
Meisel, H., \& Frister, H. (1989). Chemical characterization of bioactive peptides from in-vivo digestion of casein. Journal of Dairy Research, 56(3), 343-349.

Meisel, H., Frister, H., \& Schlimme, E. (1989). Biologically active peptides in milk proteins. Zeitschrift für Ernaehrungswissenschaft, 28(4), 267-278.

Meisel, H., Goepfert, A., \& Günther, S. (1997). ACE-inhibitory activities in milk products. Milchwissenschaft, 52(6), 307-311.

Meisel, H., \& Günther, S. (1998). Food proteins as precursors of peptide modulating human cell activity. Die Nahrung, 42(2), 175-176.

Meisel, H., \& Schlimme, E. (1990). Milk proteins: Precursors of bioactive peptides. Trends in Food Science and Technology, 1(2), 41-43.

Meisel, H., \& Schlimme, E. (1994). Inhibitors of angiotensinconverting-enzyme derived from bovine casein (casokinins). In V. Brantl, \& H. Teschemacher (Eds.), $\beta$-Casomorphins and related peptides: Recent developments (pp. 27-33). Weinheim: VCH, Germany.

Meisel, H., Bernard, H., Fairweather-Tait, S., FitzGerald, R. J., Hartmann, R., Lane, C. N., McDonagh, D., Teucher, B., \& Wal, J. M. (2003). Detection of caseinophosphopeptides in the distal ileostomy fluid of human subjects. British Journal of Nutrition, 89(3), 351-359.

Mellander, O. (1950). The physiological importance of the casein phosphopeptide calcium salts. 11. Peroral calcium dosage of infants. Acta of the Society of Medicine of Uppsala, 55, 247-255.

Migloire-Samour, D., \& Jollès, P. (1988). Casein, a pro-hormone with immunomodulating role to the newborn? Experientia, 44(3), 188-193.

Migloire-Samour, D., Floch, F., \& Jollès, P. (1989). Biologically active casein peptides implicated in immunomodulation. Journal of Dairy Research, 56(3), 357-362.

Minkiewicz, P., Slangen, C. J., Dziuba, J., Visser, S., \& Mioduszewska, H. (2000). Identification of peptides obtained via hydrolysis of bovine casein by chymosin using HPLC and mass spectrometer. Milchwissenschaft, 55(1), 14-17.

Muehlenkamp, M. R., \& Warthesen, J. J. (1996). $\beta$-Casomorphins: Analysis in cheese and susceptibility to proteolytic enzymes from Lactococcus lactis ssp. cremoris. Journal of Dairy Science, 79(1), 20-26.

Mykkänen, H. M., \& Wasserman, R. H. (1980). Enhanced absorption of calcium by casein phosphopeptides in rachitis and normal chicks. The Journal of Nutrition, 110(11), 2141-2148.

Nakamura, Y., Yamamoto, N., Sakai, K., Okubo, A., Yamazaki, S., \& Takano, T. (1995). Purification and characterization of angiotensin-I-converting enzyme inhibitors from sour milk. Journal of Dairy Science, 78(4), 777-783.

Otani, H., Kihara, Y., \& Minkyu, P. (2000). The immunoenhancing property of a dietary casein phosphopeptide preparation in mice. Food and Agricultural Immunology, 12(2), 165-173.

Parker, F., Migliore-Samour, D., Floch, F., Zerial, A., Werner, G. H., Jollès, J., Casaretto, M., Zahn, H., \& Jollès, P. (1984). Immunostimulating hexapeptide from human casein: Amino acid sequence, synthesis and biological properties. European Journal of Biochemistry, 145(3), 677-682.

Pause, B., \& Lembke, J. (1993). Comparative examination of anticaries effect of cheese. II. Results and conclusions. Milchwissenschaft, 48(3), 137-141.

Pellegrino, L., Batteli, G., Resmini, P., Ferranti, P., Barone, F., \& Adeo, F. (1997). Alkaline phosphate inactivation during Grana Padano cheese-making and related effects on cheese characterization and ripening. Le Lait, 77, 217-220.

Pellegrini, A. (2003). Antimicrobial peptides from food proteins. Current Pharmaceutical Design, 9(16), 1225-1238. 
Peres, J. M., Bouhallab, S., Petit, C., Bureau, F., Maubois, J. L., Arhan, P., \& Bougle, D. (1998). Improvement of zinc intestinal absorption and reduction of zinc/iron interaction using metal bound to the caseinophosphopeptide $1-25$ of $\beta$-casein. Reproduction, Nutrition \& Development, 38(4), 465-472.

Perpetuo, E. A., Juliano, L., \& Lebrun, I. (2003). Biochemical and pharmacological aspects of two bradykinin-potentiating peptides obtained from tryptic hydrolysis of casein. Journal of Protein Chemistry, 22(7/8), 601-606.

Petrilli, P. F., Addeo, F., \& Chianese, L. (1983). Primary structure of water buffalo $\beta$-casein tryptic and $\mathrm{CNBr}$ peptides. Italian Journal of Biochemistry, 32(5), 336-344.

Pihlanto-Leppälä, A., Antila, P., Mantsala, P., \& Hellman, J. (1994). Opioid peptides produced by in vitro proteolysis of bovine caseins. International Dairy Journal, 41(4), 291-301.

Pihlanto, A., \& Korhonen, H. (2003). Bioactive peptides and proteins. Advances in Food and Nutrition Research, 47, 175-276.

Pihlanto-Leppälä, A., Marnila, P., Hubert, L., Rokka, T., \& Korhonen, H. J. T. (1999). The effect of $\alpha$-lactalbumin and $\beta$ lactoglobulin hydrolysates on the metabolic activity of Escherichia coli JM103. Journal of Applied Microbiology, 87(4), 540-545.

Pihlanto-Leppälä, A., Rokka, T., \& Korhonen, H. (1998). Angiotensin I-converting enzyme inhibitory peptides derived from bovine milk proteins. International Dairy Journal, 8(4), 325-331.

Qian, Z. Y., Jollès, P., Migliore-Samour, D., Schoentgen, F., \& Fiat, A. M. (1995). Sheep $\kappa$-casein peptides inhibit platelet aggregation. Biochimica et Biophysica Acta, 1244(2-3), 411-417.

Recio, I., \& Visser, S. (1999). Identification of two distinct antibacterial domains within the sequence of bovine $\alpha_{\mathrm{s} 2}$-casein. Biochimica et Biophysica Acta, 1428(2/3), 314-326.

Reynolds, E. C. (1987). The prevention of surface demineralisation of bovine enamel and change in plaque composition by casein in intra-oral model. Journal of Dental Research, 66(6), 1120-1127.

Reynolds, E. C. (1994). Anticariogenic casein phosphopeptide. 24th International Dairy Congress. Melbourne, Australia, 18-22 September.

Reynolds, E. C., Riley, P. F., \& Adamson, N. J. (1994). A selective purification procedure for multiple phosphoseryl-containing peptides and methods for their identification. Analytical Biochemistry, 217(2), 277-284.

Richardson, B. C., \& Mercier, J. C. (1979). The primary structure of the bovine $\beta$-caseins. European Journal of Biochemistry, 99(2), 285-297.

Rigo, J., Boehm, G., Georgi, G., Jelinek, J., Nyambugabo, K., Sawatzki, G., \& Studzinski, F. (2001). An infant formula free of glycomacropeptide prevents hypothreoninemia in infant formulafed preterm infants. Journal of Pediatric Gastroenterology and Nutrition, 32(2), 127-130.

Roudot-Algaron, F., le Bars, D., Kerhoas, L., Einhorn, J., \& Gripon, J. C. (1994). Phosphopeptides from Comté cheese: Nature and origin. Journal of Food Science, 59(3), 544-547.

Ryhänen, E.-L., Pihlanto-Leppälä, A., \& Pahkala, E. (2001). A new type of ripened, low-fat cheese with bioactive properties. International Dairy Journal, 11(4-7), 441-447.

Saito, T., Nakamura, T., Kitazawa, H., Kawai, Y., \& Itoh, T. (2000). Isolation and structural analysis of antihypertensive peptides that exist naturally in Gouda cheese. Journal of Dairy Science, 83(7), 1434-1440.

Sandre, C., Gleizes, A., Forestier, F., Gorges-Kergot, R., Chilmonczyk, S., Leonil, J., Moreau, M. C., \& Labarre, C. (2001). A peptide derived from bovine $\beta$-casein modulates functional properties of bone marrow-derived macrophages from germfree and human flora-associated mice. The Journal of Nutrition, 131(11), 2936-2942.

Sato, R., Naguchi, T., \& Naito, H. (1986). Casein phosphopeptide (CPP) enhances calcium absorption from the ligated segment of rat small intestine. Journal of Nutritional Science and Vitaminology, 32(1), 67-76.

Schlimme, E., \& Meisel, H. (1995). Bioactive peptides derived from milk proteins. Structural, physiological and analytical aspects. Die Nahrung, 39(1), 1-20.

Sforza, S., Ferroni, L., Galaverna, G., Dossena, A., \& Marchelli, R. (2003). Extraction, semi-quantification, and fast on-line identification of oligopeptides in Grana Padano cheese by HPLC-MS Journal of Agricultural and Food Chemistry, 51(8), 2130-2135.

Shah, N. P. (2000). Effects of milk-derived bioactives: An overview. British Journal of Nutrition, 84(Suppl. 1), S3-S10.

Smacchi, E., \& Gobbetti, M. (1998). Peptides from several Italian cheeses inhibitory to proteolytic enzymes of lactic acid bacteria, Pseudomonas fluorescens ATCC 948 and to the angiotensin I-converting enzyme. Enzyme and Microbial Technology, 22(8), 687-694.

Smacchi, E., \& Gobbetti, M. (2000). Bioactive peptides in dairy products: Synthesis and interaction with proteolytic enzymes. Food Microbiology, 17(2), 129-141.

Stan, E. I., Ekimovskii, A. P., Aleinik, S. I., \& Zhuravlev, B. V. (1988). Heterogeneity and physiological activity of bovine $\kappa$-casein proteolysis products. Voprosy Pitaniia, 1, 39-43.

Sturner, R. A., \& Chang, K. J. (1988). Opioid peptide content in infant formulas. Pediatric Research, 23, 4-10.

Sun, Z., Zhang, Z., Wang, X., Cade, R., Elmir, Z., \& Fregly, M. (2003). Relation of $\beta$-casomorphin to apnea in sudden infant death syndrome. Peptides, 24(6), 937-943.

Svedberg, J., de Haas, J., Leimenstoll, G., Paul, F., \& Teschemacher, H. (1985). Demonstration of a $\beta$-casomorphin immunoreactive material in in vivo digest of bovine milk and in small intestine contents after bovine milk ingestion in adult humans. Peptides, 6(5), 825-830.

Tauzin, J., Miclo, L., \& Gaillard, J.-L. (2002). Angiotensin-Iconverting enzyme inhibitory peptides from tryptic hydrolysate of bovine $\alpha_{\mathrm{s} 2}$-casein. FEBS Letters, 531(2), 369-374.

Teschemacher, H. (2003). Opioid receptor ligands derived from food proteins. Current Pharmaceutical Design, 9(16), 1331-1344.

Teschemacher, H., \& Brantl, V. (1994). Milk protein derived atypical opioid peptides and related compounds with opioid antagonist activity. In V. Brantl, \& H. Teschemacher (Eds.), $\beta$-Casomorphin and related peptides: Recent developments (pp. 3-17). Weinheim: VCM, Germany.

Teschemacher, H., Koch, G., \& Brantl, V. (1997). Milk proteinderived opioid receptor ligands. Biopolymers, 43(2), 99-117.

Tirelli, A., de Noni, I., \& Resmini, P. (1997). Bioactive peptides in milk products. Italian Journal of Food Science, 9(2), 91-98.

Tomita, M., Takase, M., Bellami, W., \& Shimamura, S. (1994). A review: The active peptide of lactoferrin. Acta Paediatrica Japonica, 36(5), 585-591.

Wal, J. M. (2002). Cow's milk proteins/allergens. Annals of Allergy, Asthma \& Immunology, 89(6 Suppl. 1), 3-10.

Walker-Smith, J. (2003). Hypoallergenic formulas: Are they really hypoallergenic? Annals of Allergy, Asthma \& Immunology, $90(6$ Suppl. 3), 112-114.

$\mathrm{Xu}$, R.-J. (1998). Bioactive peptides in milk and their biological and health implications. Food Reviews International, 14(1), 1-16.

Yamamoto, N., Akino, A., \& Takano, T. (1994a). Antihypertensive effects of the peptides derived from casein by an extracellular proteinase from Lactobacillus helveticus CP790. Journal of Dairy Science, 77(4), 917-922.

Yamamoto, N., Akino, A., \& Takano, T. (1994b). Antihypertensive effects of different kinds of fermented milk in spontaneously hypertensive rats. Bioscience, Biotechnology and Biochemistry, 58, 776-778

Yamamoto, N., Maeno, M., \& Takano, T. (1999). Purification and characterization of an antihypertensive peptide from a yogurt-like 
product fermented by Lactobacillus helveticus CPN4. Journal of Dairy Science, 82(7), 1388-1393.

Yoshikawa, M., Tani, F., Shiota, H., Usui, H., Kurahashi, K., \& Chiba, H. (1994). Casoxin D, an opioid antagonist/ileum-contracting/vasorelaxing peptide derived from human casein. In V. Brantl, \& H. Teschemacher (Eds.), $\beta$-Casomorphins and related peptides: Recent developments (pp. 43-48). Weinheim: VCH, Germany.
Zhang, C., Hou, Y., \& Su, Y. (1998). Study on immunologic regulation action of $\mathrm{Ru}$ Zhen. China Dairy Industry, 26(2), 26-27.

Zucht, H. D., Raida, M., Adermann, K., Magert, H. J., \& Forssman, W. G. (1995). Casocidin-I: A casein $\alpha_{\mathrm{s} 2}$-derived peptide exhibits antibacterial activity. FEBS Letters, 372(2-3), $185-188$. 